\title{
Manaus nas margens da melancolia
}

\author{
Cristiane de Mesquita Alves* \\ José Guilherme de Oliveira Castro**
}

\begin{abstract}
Resumo
A cidade é também um texto que se ler em uma narrativa. Sua cartografia subjetivada no enredo literário assume um papel de interpretação tão importante, quanto ao de espaço físico-geográfico, e dos demais elementos narrativos analisados nas obras literárias. Diante desse pressuposto é que se articula a discussão deste artigo, analisar a cidade e sua manifestação subjetivada e alegórica a partir do olhar da cidade de Manaus e do flâneur que perambula por ela: Nael, com base na leitura do romance Dois Irmãos (2000) de Milton Hatoum; objetivando compreender como se processa a formação da melancolia no olhar de Manaus confluindo e se correspondendo com a melancolia do ser, do narrador-personagem Nael.
\end{abstract}

Palavras-chave: Cidade. Manaus. Melancolia.

\section{Manaus en los márgenes de la melancolía}

\begin{abstract}
Resumen
La ciudad es tambiém un texto que se leer en una narrativa. Su cartografía subjetivada en el enredo literário asume un papel de interpretación tan importante, cuanto al de espacio físico-geográfico, y de los demás elementos narrativos analisados en las obras literárias. Delante de ese presupuesto es que se articula la discusión de este artículo, analisar la ciudad y su manifestación subjetivada y alegoría la partir de la mirada de la ciudad de Manaus y del flaneur que deambula por ella: Nael, con base en la lectura del romance Dos Hermanos (2000) de Milton Hatoum; objetivando compreender como se procesa la formación de la melancolia en la mirada de Manaus confluindo y se correspondiendo con la melancolia del ser, del narrador-personaje Nael.
\end{abstract}

Palabras-llave: Ciudad. Manaus. Melancolia.

Recebido: 30/03/2018

Aceito: $27 / 11 / 2018$

\footnotetext{
* Universidade da Amazônia (UNAMA). Doutoranda em Comunicação, Linguagens e Cultura pelo PPGCLC. Bolsista Prosup/CAPES. Integrante do Grupo de Pesquisa Interfaces do Texto Amazônico (GITA). O presente trabalho foi realizado com o apoio da Coordenação de Aperfeiçoamento de Pessoal de Nível Superior- Brasil (CAPES)- Código de Financiamento 001. Portaria No 206, de 04 de Setembro de 2018

** Universidade da Amazônia (UNAMA - PA). Professor Titular. Coordenador do Grupo de Pesquisa Interfaces do Texto Amazônico (GITA). Doutor em Letras pela PUC- RS.
} 


\section{Introdução}

Em tudo eu pude ver ainda a tua imagem,

A imagem que inspirava os castos madrigais;

E as virações, o rio, os astros, a paisagem,

Traziam-me à memória idílios imortais.

Diziam-me que tu, no flórido passado,

Detinhas sobre mim, ao pé daquelas rosas,

Aquele teu olhar moroso e delicado,

Que fala de langor e de emoções mimosas;

(VERDE, 2003, p. 50).

A cidade é o espaço ideal para entender a natureza das formas contemporâneas de sociabilidade e de experiências humanas; ela simboliza um dispositivo metafórico usado para representar espaços de desenvolvimento da vida moderna. Por este motivo, nos textos literários, a passagem da cidade, não só como um espaço descritivo físico e geográfico onde as ações se desenvolvem, mas também como um texto em que a cidade é também protagonista, deve ser levado em consideração no processo de análise dos dados narrativos em que ela está inserida.

A cidade "é, então, fonte de alegorias" (FEATHERSTONE, 2000, p. 191), que serve para se referir à confusão de mercadorias e fragmentos de culturas que circulam livremente por ela, fazendo-a palco das experiências memorialísticas, contemporâneas e das transformações humanas e sociais, em que ela também vai se configurando, transformando-se no meio desse processo; assim a cidade se hibridiza com o humano e as coisas que estão nela ou passaram por ela.

Nesse processo de (trans)formação constante da cidade, vai-se moldando sua cartografia simbólica, visualizada e sentida pela situação dialogal entre ela e entre os seus interlocutores, criando nas grafias urbanas um relato sensível dos modos de ver a cidade, em que o imaginário individual do sujeito se cruza com o da coletividade, enquanto um símbolo complexo responsável por exprimir a tensão entre a racionalidade geométrica e o emaranhado de existências e experiências humanas presente nela (GOMES, 1997).

Diante disso, refletir acerca das representações da cidade nas cenas escritas nas páginas da literatura é "ler textos que lêem a cidade" (GOMES, 1997, p. 179). É entender a cidade como um discurso significativo e intrínseco a fala de seus habitantes, uma vez que ela é o espelho de seus dândis, "a cidade como diz de Certeau, de caminhantes que escrevem a cidade sem poder lê-la." (FEATHERSTONE, 2000, p. 191); ela é o resultado da vivência, da história, da memória, da leitura, e da construção do sujeito que a lê, enquanto espaço físico, dotado de sensibilidades, de mitos, condensação simbólica cultural.

Além disso, percebe-se que a cidade na literatura é a representação do cenário de mudança, em busca de significação a respeito dela mesma e de seu "grande deserto de homens" (BAUDELAIRE, 1996, p. 24) que ecoa suas múltiplas vozes e sentidos na formação do imaginário social da memória coletiva a individual (HALBWACHS, 2013) em um imenso aglomerado de rios e ruas que mapeiam o espaço e a vida desse sujeito e dessa cidade nesses quadros urbanos, cada vez mais solitários no desenvolvimento tecnológico globalizado.

Assim, escrever sobre a cidade "é também lê-la, mesmo que ela se mostre ilegível à primeira vista; é engendrar uma forma para essa realidade sempre móvel." (GOMES, 1997, p. 179), e, é dentro desta perspectiva que se apresenta a cidade de Manaus, de como ela vê e é vista a partir do olhar de Nael, sujeito solitário que caminha pelas ruas e pelos rios que a forma, narrador e, também a personagem mais interessante do livro (ALVES, 2017), Dois Irmãos de Milton Hatoum. E, para se estabelecer este discurso mútuo entre Nael e Manaus, partiu-se da análise comportamental dos dois, manifestada pelo teor melancólico. 
Homem livre, terás pelo mar sempre amor,

O mar é teu espelho; contemplas a tua alma

No infinito rolar de sua lâmina calma,

A tua alma não tem um menor amargor

Gostas de mergulhar no fundo de tua imagem;

Tu o abraças com o olhar, braços, teu coração

Às vezes se distrai com teu ruído vão

Ao som desse queixume indomável, selvagem.

(BAUDELAIRE, 2011, p. 39).

Manaus é a cidade alegórica no romance de Hatoum mapeada por uma cartografia simbólica, ultrapassando a noção meramente geográfica de espaço físico, como muitas das cidades presentes nos textos da Literatura (GOMES, 1997). Seu mapa é aberto sobre um plano de múltiplas consistências e de entradas, que o caracteriza ao mapa de Deleuze \& Guattari (2011), proposto como um novo conceito de cartografia, baseado na ideia filosófica em que busca novas significações. Uma das quais, possibilita interpretar a cidade de Manaus, muito além de seu plano objetivo: o de cidade geográfica, mas também, proporciona vê-la em seu espaço subjetivo, por meio das descrições de seus cheiros e rios, sua melancolia diante da destruição de seus lugares, de sua natureza, pelo processo de industrialização e pela globalização impostos pelos grandes projetos econômicos na Amazônia. Tal descrição de novo mapa configurado em Manaus, permite escrevê-lo como um rizoma, no qual seu território passa por um processo de desterritorialização, como um dos "princípios de cartografia e de descalcomania: [em que] um rizoma não pode ser justificado por nenhum modelo estrutural ou gerativo" (DELEUZE; GUATTARI, 2011, p. 29), o que possibilita nesta leitura, analisá-la enquanto uma cidade de cartografia, muito além da física.

Isto posto, ao lê-la enquanto espaço-personagem, ela assume uma entidade dotada de subjetividades e sensibilidades, as quais se correlacionam as do narrador-personagem Nael, que de modo geral, apresenta-a ao leitor. Assim, a cidade manauara estrutura-se no "esqueleto da maioria das obras literárias, cujo significado específico provém da maneira peculiar de recobri-lo com nervos e músculos. Poderíamos ir até mais longe, se pensarmos na correlação simbólica dos ambientes iniciais do livro." (CANDIDO, 1993, p. 65).

Dentre essas sensações sentidas e captadas pelo olhar e pelo corpo da cidade, de maneira muito expressiva na narrativa de Dois Irmãos, está a presença da melancolia, tão recorrente entre as imagens das descrições da cidade feitas por Nael, quando constrói as imagens da cidade corroborando ao discurso de que a "alegoria é o corpo ou a sombra da melancolia" (STAROBINSKI, 2014, p. 16), confirmando a premissa de que

Toda narrativa é de alguma forma tributária de um impulso melancólico, pois ao mesmo tempo que atualiza eventos do passado reafirma o seu caráter por definição passado, isto é, que passou, morreu, deixou de existir e, portanto, pranteável. O que é a história [...], senão uma outra espécie de narrativa fundamentalmente melancólica, cujo objeto de estudo encontra-se ausente, inalcançável (LAGES, 2007, p. 131).

Diante dessa ausência de si, no caso de Manaus, perdendo-se na própria glória do passado (Ciclo da Borracha), e vendo-se destruída, mais uma vez pela implantação de um novo modelo de cidade, que representasse a modernidade, que já trouxe em seu cerne a ideia de que o mundo pode ser transformado, em que rejeita o mundo tal como ele tem sido no passado e toma para si a decisão de transformá-lo, justificando-se pela "A moderna forma de ser consiste na mudança compulsiva obsessiva: na refutação do que "meramente é" em nome do que poderia - e no mesmo sentido deveria - ser posto em seu lugar.” (BAUMAN, 2005, p. 34), Manaus de forma amarga se encontra às margens 
de seu Rio Negro.

E, nesse processo de perda pela transformação imposta pela modernidade, sua forma de ainda se encontrar, é articular-se ao passado, mas com o pressuposto benjaminiano de que "articular historicamente o passado não significa conhecê-lo "tal como ele de fato foi". Significa apropriar-se de uma recordação, como ela relampeja no momento de perigo.” (BENJAMIN, 2012, p. 243), e, desse jeito, faz Manaus para evitar seu esquecimento, e de alguma forma, manter-se lembrada, uma vez que o mundo moderno é um mundo que contém um desejo e uma determinação de desafiar a mesmice, já que a "opção é modernizar-se ou perecer." (BAUMAN, 2005, p. 34), e quem se recusa a este processo pode se ver rejeitado e abandonado, ou continuar propício a um desgaste que se trava contra a natureza em curso, como se estivesse sendo castigado pelo sistema capitalista imposto, por não se inserir nele, como se observa nas precárias condições de vida em Manaus:

\footnotetext{
Noites de blecaute no norte, enquanto a nova capital do país estava sendo inaugurada. A euforia, que vinha de um Brasil tão distante, chegava a Manaus como um sopro amornado. E o futuro, ou a ideia de um futuro promissor, dissolvia-se no mormaço amazônico. Estávamos longe da era industrial e mais longe ainda do nosso passado grandioso. Zana, que na juventude aproveitara os resquícios desse passado, agora se irritava com a geladeira a querosene, com o fogareiro, com o jipe mais velho de Manaus, que circulava aos sacolejos e fumegava (HATOUM, 2000, p. 128).
}

Esse passado glorioso, marcado pela tristeza do presente, contribui para a reconfiguração do mapa rizomático de Manaus, "mapa que deve ser produzido, construído, sempre desmontável, conectável, reversível, modificável, com múltiplas entradas e saídas, com suas linhas de fuga." (DELEUZE; GUATTARI, 2011, p. 43), que são encontradas pela melancolia do espaço manauara, consequentemente refletida nos seus passantes, já que "os ambientes iniciais do livro em termos polares as opções que regem os atos dos personagens, vinculando-os aos líquidos, que a aparecem nos níveis natural, social, metafórico e simbólico." (CANDIDO, 1993, p. 66).

Se as personagens leem a cidade, ela também o faz em relação a eles, isto é, a cidade repete uma vida idêntica a de seus habitantes, "Os habitantes voltam a recitar as mesmas cenas com atores diferentes, contam as mesmas anedotas com diferentes combinações de palavras; escancaram as bocas alternadamente com bocejos iguais." (CALVINO, 1990, p. 39), nesse interdiscurso, a cidade se torna um elemento "muito importante para compreender a função do ambiente, tomado ao mesmo tempo como condicionamento e símbolo, são as metamorfoses sofridas” (CANDIDO, 1993, p. 75).

E dessas metamorfoses sofridas pela cidade de Manaus na contextualização do romance de Hatoum em discussão está a melancolia.

\section{Manaus diante do reflexo de seu flâneur}

A natureza é um templo onde vivos pilares Por vezes dão a ouvir palavras muito estranhas; Nas florestas dos símbolos o homem emaranha Que o observam com olhos bem familiares.

Tais longos ecos que ao longe se escondem Em uma tenebrosa e profunda unidade, Tão vasta como a noite e como a claridade As cores, os perfumes e os sons respondem (BAUDELAIRE, 2011, p. 31).

A melancolia se caracteriza por um desâmino profundamente doloroso, pela inibição da capacidade para realização, que "se expressa em autorrecriminações e autoinsultos, até atingir a expectativa delirante de punição.” (FREUD, 2016, p.100). O sujeito melancólico mostra que algo lhe falta, 
provocando em si um sentimento de rebaixamento em sua autoestima, tornando-se um Eu indigno, "incapaz e moralmente desprezível; ele se recrimina, insulta-se e espera ser rejeitado e castigado." (FREUD, 2016, p. 103). Ele não julga que uma mudança lhe aconteceu, mas estende sua autocrítica ao passado, e como o "a verdadeira imagem do passado passa voando. O passado só se deixa capturar a imagem que relampeja irreversivelmente no momento de sua conhecibilidade." (BENJAMIN, 2012, p. 243).

Diante disso, ao narrar sua história e, consequentemente, a história da cidade de Manaus, Nael se vê melancólico frente a uma cidade alagada, melancólica e ilhada em seu passado glorioso, reduzindose a ruínas, graças às modificações urbanas advindas do desenvolvimento capitalista, que ao impor a civilização urbana e tecnológica pela implantação da Zona Franca na cidade, seus rios de ruas foram sendo substituídos bruscamente por avenidas largas, shoppings e boulevards, configurando a geografia do espaço em uma que correspondesse à modernização, caracterizada pela progressão de modo triunfante da quase totalidade da produção e do consumo humanos que se tornou "mediada pelo dinheiro e pelo mercado [...] pela comercialização e a monetarização dos modos de subsistência dos seres humanos penetraram os recantos mais longínquos do planeta" (BAUMAN, 2005, p. 13), e dentre esses lugares, Manaus que era um dos espaços promissores para este mundo visionário do dinheiro, também foi obrigada a se inserir, como se observa na passagem:

O que enraizava em cada lugar eram os negócios. Ouvira dizer que Manaus crescia muito, com suas indústrias e seu comércio. Viu a cidade agitada, os painéis luminosos com letreiros em inglês, chinês e japonês. Percebeu que sua intuição não falhara (HATOUM, 2000, p. 226).

Em vista disso, a cidade foi se transformando, assim como Nael, os dois às margens da melancolia, sendo como um o espelho do outro, refletindo as dores e as ruínas de suas próprias existências, e nessa experiência de trocas afetivas melancólicas entre Nael e Manaus, o peso do sentimento de amor pelo lugar, de pertencimento, faz-se inevitável, pois ao relatar suas memórias sobre sua vida e sobre a vida da cidade, Nael não hesita em descrever amargamente a dor de ter perdido as pessoas e a cidade de outrora, quando relembra os pequenos comércios nas ruas da cidade, o porto e a igreja quando caminhava, "Ali o movimento era de multidão: um vaivém noite e dia. Fechariam o restaurante, porque todos aqueles clientes, com suas anedotas obscenas, histórias de naufrágio e seres encantados, lembravam-lhe o pai." (HATOUM, 2000, p. 64), criando uma referência identitária com o lugar, e com as pessoas que participaram e viveram sua vida com ele, como o seu avô Halim:

\footnotetext{
Ele me levava para um boteco na ponta da Cidade Flutuante. Dalí podíamos ver os barrancos dos Educandos, o imenso igarapé que separa o bairro anfíbio do centro de Manaus. Era a hora do alvoroço. O labirinto de casas erguidas sobre os troncos fervilhava: um enxame de canoas navegava ao redor das casas flutuantes, os moradores chegavam do trabalho, caminhavam em filas sobre as tábuas estreitas, que formam uma teia de circulação. Os mais ousados carregavam um botijão, uma criança, sacos de farinha: se não fossem equilibristas, cairiam no Negro. Um ou outro sumia na escuridão do rio e virava notícia (HATOUM, 2000, p. 120).
}

Neste processo de andarilho pela cidade e a cidade o observando, Nael busca uma imersão nas sensações da cidade "Aos domingos, [...] passeava ao léu pela cidade, atravessava as pontes metálicas, perambulava nas áreas margeadas por igarapés, os bairros que se expandiam àquela época, cercando o centro de Manaus." (HATOUM, 2000, p. 80), perde-se nas sensações, sucumbir-se ao arrasto de desejos aleatórios e aos prazeres, e ao registrar suas impressões, durante a caminhada pela Cidade Flutuante, descrevendo e vivendo o lugar, desenvolve sua sensibilidade "estética nas oscilações entre desenvolvimento e distanciamento, entre imersão emocional e descontrole, momentos de registros e análise cuidadosa [...] de impressões de ruas." (FEATHERSTONE, 2000, p. 192), aproximandose do flâneur, observador apaixonado, “[...]. Estar fora de casa, e contudo sentir-se em casa onde quer que se encontre; ver o mundo, estar no centro do mundo e permanecer oculto no mundo, eis 
alguns dos pequenos prazeres desses espíritos independentes" (BAUDELAIRE, 1996, p. 20), por isso, a dor de Nael se identifica com a dor alegórica de Manaus, vendo-se destruída pela reconstrução do urbanismo, sentindo-se as dores da alteração profunda de sua paisagem, como consequência da ascensão da indústria e da burguesia.

Essa alegoria seria, então, "o cúmulo da melancolia: meio de conjurar a passagem do tempo e as imagens da destruição, certamente, mas ao custo de paralisar toda a vida, lançando sobre si mesmo e sobre o mundo um olhar de Medusa ..." (STARONBINSKI, 2014, p. 69), um olhar que se a cidade pudesse ou o próprio narrador petrificariam as ações invasoras tão impostas e injustas na cidade, pelo poder do Governo Militar no chamado plano de Metas para o desenvolvimento da Amazônia, em que cidades inteiras se viram castigadas pelas ações mal planejadas pelo Governo e até hoje, ficaram submersas em uma suposta modernidade, confinadas ao esquecimento político ou a "despejos e de ferramentas para a reciclagem do lixo" (BAUMAN, 2005, p. 13), ou na própria nomeação de Hatoum: A cidade ilhada.

Isso traduz de certo modo, a representação dos dados concretos particulares que produz na ficção o senso da realidade, como uma forma de "sugestão de uma certa generalidade, que olha os dois lados e dá consistência tanto aos dados particulares do real quanto aos dados particulares do mundo fictício." (CANDIDO, 1993, p. 45). Diante disso, Manaus representa o olhar que percorre as suas próprias ruas e os seus rios na amargura de "uma crise aguda da indústria de remoção do refúgio humano" (BAUMAN, 2005, p. 13), quando viu seus moradores sendo remanejados para dá espaço a sua nova arquitetura, como acontece com o próprio casarão árabe da família dos avôs de Nael, vendido para se tornar a "Casa Rochiram, um carnaval de quinquilharias importadas de Miami e do Panamá, encheu as vitrines.” (HATOUM, 2000, p. 255), exemplificando a expansão global da forma de vida moderna que liberou e pôs movimento a "quantidades enormes e crescentes de seres humanos destituídos de formas e meios de sobrevivência." (BAUMAN, 2005, p. 14), característica do capitalismo em que a cidade agora estava mergulhada e se afundando. E, essa angústia se consolidou quando a Cidade Flutuante foi demolida:

Assistiam, atônitos, à demolição da Cidade Flutuante. Os moradores xingavam os demolidores, não
queriam morar longe do pequeno porto, longe do rio. Halim balançava a cabeça, revoltado, vendo
todas aquelas casinhas serem derrubadas. Erguia a bengala e soltava uns palavrões, gritava "Por que
estão fazendo isso? Não vamos deixar, não vamos", mas os policiais impediam a entrada no bairro.
Ele ficou engasgado, e começou a chorar quando viu as tabernas e o seu bar predileto, A Sereia do
Rio, serem desmantelados a golpes de machado. Chorou muito enquanto arrancavam os tabiques,
cortavam as amarras dos troncos flutuantes, golpeavam brutalmente os finos pilares de madeira. Os
telhados desabavam, caibros e ripas caíam na água e se distanciavam da margem do Negro. Tudo
se desfez num só dia, o bairro todo desapareceu. Os troncos ficaram flutuando, até serem engolidos
pela noite (HATOUM, 2000, p. 211).

Vê esta destruição, motiva tanto Nael, quanto Manaus alimentarem o que instinto melancólico, já embutido no Eu desses dois personagens de Dois Irmãos, que são destruídos paulatinamente pela sociedade de valores burgueses, nesse momento, corrobora a ideia de sensação de melancolia a "espelho castrador" (STARONBINSKI, 2014, p. 35), pois os dois são castrados de sua liberdade subjetiva. Manaus não tem mais só seus rios, Nael não tem mais suas ruas em rios, já que os fluxos dos carros e a velocidade da cidade grande chegam a Paris das Selvas.

E "Via um mundo naqueles recantos, a cidade que não vemos, ou não queremos ver. Um mundo escondido, ocultado, cheios de seres que improvisaram tudo para sobreviver." (HATOUM, 2000, p. 80-81) foi ameaçado pela mudança da globalização que tentou modificar Manaus e a partir disso, Manaus deixou de ser a mesma. Aquele cotidiano:

Apoiado no parapeito, Yaqub olhava os passantes que subiam a rua na direção da praça dos Remédios. 
Por ali circulavam carroças, um e outro carro, cascalheiros tocando triângulos de ferro; na calçada, cadeiras em meio círculo esperavam os moradores para a conversa do anoitecer; no batente das janelas, tocos de velas iluminariam as noites da cidade sem luz. Fora assim durante os anos da guerra: Manaus às escuras, seus moradores acotovelando-se diante dos açougues e empórios, disputando um naco de carne, um pacote de arroz, feijão, sal ou café. Havia racionamento de energia, e um ovo valia ouro. Zana e Domingas acordavam de madrugada, a empregada esperava o carvoeiro, a patroa ia ao Mercado Adolpho Lisboa e depois as duas passavam a ferro, preparavam a massa do pão, cozinhavam. Quando tinha sorte, Halim comprava carne enlatada e farinha de trigo que os aviões norte-americanos traziam para a Amazônia. Às vezes, trocava víveres por tecido encalhado: morim ou algodão esgarçado, renda encardida, essas coisas (HATOUM, 2000, p. 22-23).

Foi modificado pelo olhar mercadológico e ameaçador do Governo Militar e do Capital estrangeiro, no romance exemplificado pelo indiano Rochiram. Agora, $\mathrm{O}$ discurso que dá a ver a cidade que deveria ser visível, não se faz presente, pois Manaus ficou abandonada e desprotegida, bem como Nael. Seu desenvolvimento tardio e incompleto fez com que suas alegorias estivessem associadas basicamente “a arquitetura da cidade [que está] 'desde sempre em ruínas”,, (FEATHERSTONE, 2000, p. 191).

$\mathrm{E}$, se "a modernidade elegeu o futuro como tempo privilegiado e identificou-se com a mudança, assimilando-a ao progresso.” (GOMES, 1997, p. 188), nessa perspectiva, se a cidade de Manaus - transitoriedade permanente - foi pensada como lugar e objeto dessa mudança capitalista, com o desenvolvimento tecnológico da Zona Franca de Manaus, esse processo de modernização, não chegou, e se chegou foi destruidor e incompleto! Manaus assim como as demais cidades, apresentadas como planos de fundo ou mesmo personagens alegóricas das ações, tornou-se mais um exemplo de cidadeproblemática, com um palco de violências e manifestações sociais, que no caso de Dois Irmãos, essa crise pode ser observada na loja de Halim, atravessada pela violência, pela desestabilização de valores, de anarquia pela ação dos estudantes do Galinheiro dos Vândalos, em defesa das opiniões políticas defendidas pelos alunos e pelo professor Antenor Laval - frente às forças do Governo Militar, dentre outras ações sociais presentes no romance:

Humilhado no centro da Praça das Acácias, esbofetado como se fosse um cão vadio à mercê da sanha de sangue feroz. Seu paletó branco explodiu de vermelho e ele rodopiou no centro do coreto, as mãos cegas procurando um apoio. [...] A vaia e os protestos de estudantes e professores do liceu não intimidaram os policiais. Laval foi arrastado para um veiculo do Exército, e logo depois as portas do Café Mocambo foram fechadas. Muitas portas foram fechadas quando dois dias depois soubemos que Antenor Laval estava morto. [...] Na manhã da caçada ao mestre eu apanhei a pasta surrada, perdida na beira do lago. Dentro da pasta, os livros e as folhas com poemas, cheias de manchas. [...] Ele não queria ser chamado de poeta, não gostava disso. Detestava pompa, ria dos políticos (HATOUM, 2000, p. 189-190).

Como se observa na narrativa de Hatoum, a cidade representa um caderno de vários discursos políticos, climáticos e geográficos, de violência, de solidão, de valores humanos corroídos, semelhantes à estrutura descuidada, com rachaduras nas paredes da cidade; é um lugar formador de opiniões que desafia o olhar do habitante, de quem lê e de quem busca um caráter afetuoso com o espaço. Mas, que aos poucos vai perdendo a referência aos valores do passado, ficando à beira, à margem da melancolia de quem ressente a dor de um passado glorioso, que não volta.

Manaus, em Dois Irmãos, encena em um palco atrofiado, sem acabamento digno de uma Belle Époque que tanto a glorificou no passado. Seu rio Negro está às escuras do sofrimento, e seu reflexo "reduzir-se a mera superfície refletora: a consciência transmutada em espelho [que] vivencia passivamente a reflexão. Ela apenas suporta as formas e as criaturas que se postam a sua frente, a fim de devolver-lhes o reflexo." (STARONBINSKI, 2014, p. 34), e como nesse relato, ela vê Nael perambulando por suas ruas, melancolicamente, sádico e atroz ressentindo sua sorte, ela se reflete nele. E, 
Mesmo que durante todo o texto, ele (o narrador) se proponha e o faz o papel de contar as suas memórias e as dos outros, ele acaba se identificando como um sujeito isolado e exilado no meio de uma cidade que estava se urbanizando com a chegada do progresso e das lojas que estavam modificando o espaço de Manaus. E Nael acaba se identificando com o tão sujeito da pós-modernidade descrito por Stuart Hall (ALVES, 2017, p. 161).

Um sujeito que se fundi ao próprio espaço da cidade, considerado como um "lugar em que o fato e a imaginação teriam de se fundir, aceitando, por outro lado, o fragmentário, o descontínuo, e contemplando as diferenças" (GOMES, 1997, p. 188), assim como seus estilos, sua multiplicidade de significados, sua delegação alegórica do eu confluindo-se a outros eus, acrescentando-se a alegoria do eu, "materializando-o, convertendo-o em objeto [...]. A alegoria desta feita, não se vincula mais à personificação: ela é despersonificada, desvitalizante, Tornar-se espelho" (STARONBINSKI, 2014, p. 33), buscando dessa forma "decifrar o urbano que se situa no limite extremo e poroso entre realidade e ficção” (GOMES, 1997, p. 179).

E no romance de Hatoum, essa dupla se faz presente, fazendo com que o texto, embora apresente "seus personagens protagonistas, secundários e terciários definidos, seu autor escreve a história enveredando seu leitor a atribuir importância a todos, inclusive ao próprio espaço onde se passa a narrativa, quase um cortiço" (ALVES, 2017, p. 91, grifo da autora), fazendo uma alusão direta ao romance de Aluísio Azevedo O Cortiço publicado em 1890, em que o autor desistindo de montar um enredo em função de pessoas, "ateve-se à sequência de descrições muito precisas onde cenas coletivas e tipos psicologicamente primários fazem, no conjunto, do cortiço a personagem mais convincente do romance" (BOSI, 2006, p. 190), do mesmo modo Hatoum faz da cidade de Manaus, em muitas cenas, como também personagem.

Assim, a cidade de Manaus continua como uma paisagem inevitável e essencial ao desenrolar da narrativa. Observá-la se faz necessário para buscar informações, respostas para as perguntas das dúvidas sobre a vida de Nael, seu conflito enquanto a questão paterna, até o próprio conflito espacial em que a cidade estava passando.

Ao ser "incumbido de vasculhar o centro da cidade, entrei nas barracas espalhadas no porto da praça dos Remédios, nos pequenos restaurantes encafuados no alto dos barrancos, nos botecos do labirinto da Cidade Flutuante.” (HATOUM, 2000, p. 92), era também uma forma do próprio narrador encontrar a teia ou fio de Ariadne que o ajudasse a sair de seu próprio labirinto, que se mescla ao da condição de Manaus naquele momento, depois de sua destruição de Cidade Flutuante a Cidade Polo Industrial.

Nesse sentido, o espaço da cidade é um objeto de análise que concerne ao estudo das partes da memória coletiva do narrador e se torna como mais uma personagem que flutua na mente de Nael (ALVES, 2017), pois fez uso de suas experiências, o próprio espaço social de Manaus de sua época e seus conflitos e suas muitas opiniões em silêncio. Essas experiências são utilizadas nos espaços sociais de Manaus para contextualizar as ações de Nael. No trecho abaixo, o narrador relata como ele vivencia a realidade social de Manaus em passeios ao lado de seu avô Halim.

Parecia um sufi em êxtase quando me recitava cada par de versos rimados. Contemplava a folhagem verde e umedecida, e falava com força, a voz vindo de dentro, pronunciando cada sílaba daquela poesia, celebrando um instante do passado. Eu não compreendia os versos quando ele falava em árabe, mas ainda assim me emocionava: os sons eram fortes e as palavras vibravam com a entonação da voz. Eu gostava de ouvir as histórias. Hoje, a voz me chega aos ouvidos como sons da memória ardente. Às vezes ele se distraía e falava em árabe. Eu sorria, fazendo-lhe um gesto de incompreensão: "É bonito, mas não sei o que o Senhor está dizendo". Ele me dava um tapinha na testa, murmurava: "É a velhice, a gente não escolhe a língua da velhice. Mas tu podes aprender umas palavrinhas, querido" (HATOUM, 2000, p. 51). 
Isso se justifica pelo fato de a narrativa ser uma forma responsável por relatar aos outros, o que se passou, e aliado a ela, há uma grande importância da memória coletiva e histórica da sociedade na formação da identidade e da memória no indivíduo (HALBWACHS, 2013). A memória vai modelando o pensamento do narrador ao passo que o mesmo vai encontrando respostas para resolver seu drama, justamente para poder tecer fios, lembranças que possam se encaixar nas reflexões do narrador para poder compreender de fato, em sua trajetória, quem ele seria filho (ALVES, 2017).

E andar por Manaus é a sensação de refúgio e de alívio nos dias de folga de Nael, quando ia ao rio e ao cinema:

Mirava o rio. A imensidão escura e levemente ondulava me aliviava, me devolvia por um momento a liberdade tolhida. Eu respirava só de olhar para o rio. E era muito, era quase tudo nas tardes de folga. Às vezes Halim me dava uns trocados e eu fazia uma festa. Entrava no cinema, ouvia a gritaria da plateia ficava zonzo de ver tantas cenas movimentadas, tanta luz na escuridão. Depois eu cochilava e dormia uma, duas sessões e despertava com a lanterninha chocoalhando meu ombro. Era o fim. O fim de todas as sessões, o fim do meu domingo (HATOUM, 2000, p. 81-82).

Diante disso, o que se verifica é que Manaus, não figura no romance apenas como um meio de construção para entender a cidade contemporânea, a cidade global, a cidade que alguns chamariam de pós-moderna, mas como um modo cada vez mais significativo da experiência humana, dos que são a ela contemporâneos. O seu flâneur que se destaca nas ruas da cidade, apontando uma posição central da "locomoção na vida social: ele é constantemente invadido por ondas de experiências novas e desenvolve novas percepções enquanto cruza a paisagem urbana e as multidões." (FEATHERSTONE, 2000, p. 189), estabelecendo também com ela uma relação, no caso de Nael "esquecido e alagado" (ALVES, 2017, p. 157), em sua dor que não passa e que não se esquece.

A figura do flâneur- Nael convida o leitor do romance a desviar o olhar para um outro tempo, para o tempo em que a cidade era majestosa e encantada com seus seres mitológicos, intrínsecos no imaginário da população ribeirinha, dos cantores, poetas e dos bêbados que preenchiam o medo do escuro das ruas às margens dos rios, de poesia, de uma Manaus vital ao sujeito que se enxerga e se encontra na cidade. Seja a Manaus da época ilustre da Belle Époque do passado, seja a Manaus do século XX, marcada pelas invasões dos projetos militares ou de desenvolvimento. Nael lança sobre a cidade um olhar atento sobre o seu mundo, sobre as pessoas que escolheram o lugar para viver e se identificar com ele, os manauaras, os índios, os nordestinos, os imigrantes, os estrangeiros, sobre a vida e sobre quem lá escolheu viver.

Também lança seu olhar para a cidade, símbolo de todas essas vozes que vão se multiplicando pelos rios, estradas e florestas adentro, mesmo que esta cidade ofereça surpresas para os olhos, "Feliz é aquele que todos os dias tem Fílide ao alcance dos olhos e nunca acaba de ver as coisas que ela contém", exclama-se, triste por ter de deixar a cidade depois de tê-la olhado apenas de relance." (CALVINO, 1990, p. 54), a cidade permanece ali com suas trocas, seus olhares, e mesmo que ela vá perdendo seus passantes, sua "narrativa se ordena ao redor das coisas que nesse momento povoam o espaço.” (CANDIDO, 1993, p. 75), que vai se modificando para também modificar as pessoas.

E nessa "pluralidade de manifestações, pela particular trama entre energia vital e tensão mortal que abriga, a disposição melancólica continua estimulando a reflexão [...] continuando a se constituir num fascinante enigma do psiquismo humano." (LAGES, 2007, p. 38), servindo de alegoria para representar a vida dos sujeitos em sociedades e a cidade nos sujeitos. 


\section{Considerações Finais}

Diante do que foi exposto nas linhas passantes acima, chega-se a algumas considerações para este estudo sobre a cidade de Manaus na Literatura, que mesmo ficcionalizada torna-se uma das cidades imaginárias, ou seja, as "construções mentais e simbólicas elaboradas pela literatura sobre as realidades urbanas." (PASAVENTO, 2009, p. 1). Estas urbes transfiguradas, melancólicas ou alegóricas, servem para expressar outros mundos que constituem uma forma de leitura sensível da realidade, exercida pela escrita do texto literário.

Assim, com o desenvolvimento urbano de Manaus, visível pelas aberturas das vias públicas, lojas de departamentos, construção de condomínios, e as novas experiências urbanas presente na vida social da cidade impostas pelo sistema capitalista e as intervenções militares na década de $1960 \mathrm{em}$ diante, Manaus aos poucos vai perdendo todas as paisagens do passado em que o olhar de seu flâneur: Nael viu. Novos olhares são impostos a monotonia e beleza singular dos rios e das ruas confluídos pelas águas do rio Negro, substituídos pela velocidade, pela pressa, por novas necessidades sociais, marcando a nova configuração do espaço-água dessa cidade, mais ilhada e melancólica em sua própria dor.

Portanto, mediante a essa nova cartografia física e subjetiva da cidade, as lembranças e as associações da vida manauara vão fluindo por distrações e impressões do momento, passando a experiências de imagens que se encontram por meio de formas variadas de locomoção pela cidade, como uma viagem pela imaginação de quem a viu e foi visto pelo olhar da própria cidade, buscando nessa estranheza dos lugares e das multidões que passam pelas ruas de concreto, outrora banhadas pelo rio, pistas e vestígios de informações que remeteriam à beleza da majestosa senhora que foi construída as margens do labiríntico rio Amazonas. 


\section{Referências}

ALVES, Cristiane de Mesquita. A voz do Narrador e da personagem através da memória em Machado de Assis e Milton Hatoum. 1 ${ }^{a}$ ed. São Paulo: Paco Editorial, 2017.

BAUDELAIRE, Charles. As flores do Mal. Tradução de Mário Laranjeira. São Paulo: Martin Claret, 2011.

BAUDELAIRE, Charles. Sobre modernidade: o pintor da vida moderna. Tradução e Organização de Teixeira Coelho. Rio de Janeiro: Paz e Terra, 1996.

BAUMAN, Zygmunt. Vidas desperdiçadas. Tradução de Carlos Alberto Medeiros. Rio de Janeiro: Zahar, 2005.

BENJAMIN, Walter. Sobre conceito de História. In: BENJAMIN, Walter. Magia, técnica, arte e política: ensaios sobre literatura e história da cultura. Tradução de Sérgio Paulo Rouanet. 8 ed. São Paulo: Brasiliense, 2012. (Obras escolhidas; v.1).

BOSI, Alfredo. História Concisa da Literatura Brasileira. 43ª ed. São Paulo: Cultrix, 2006.

CALVINO, Ítalo. As cidades invisíveis. Tradução de Diogo Mainardi. São Paulo: Companhia das Letras, 1990.

CANDIDO, Antonio. O discurso e a cidade. São Paulo: Duas Cidades, 1993.

DELEUZE, Gilles; GUATTARI, FÉLIX. Mil Plâtos: capitalismo e esquizofrenia. Vol.1. Tradução de Ana Lúcia de Oliveira; Aurélio Guerra Neto e Célia Pinto Costa. 2a ed. São Paulo: Editora 34, 2011.

FEATHERSTONE, Mike. O flâneur, a cidade e a vida pública virtual. In: ARANTES, Antonio A (Org). O espaço da diferença. Campinas, São Paulo: Papirus, 2000.

FREUD, Sigmund. Luto e melancolia. In: Neurose, psicose, perversão. Tradução de Maria Rita Salzano Moraes. Obras Incompletas de Freud. v. 5. Belo Horizonte: Autêntica Editora, 2016.

GOMES, Renato Cordeiro. Cartografias urbanas: representações da cidade na literatura. Semear: Revista da Cátedra Padre António Vieira de Estudos Portugueses, Rio de Janeiro, v. 1, n. 1, p. 179188, 1997. Disponível em: <http://www.letras.puc-rio.br/catedra/revista/1Sem_12.html >. Acesso em: 24 mar. 2018.

HALBWACHS, Maurice. A memória coletiva. Tradução de Beatriz Sidou. $2^{\mathrm{a}}$ ed. $7^{\mathrm{a}}$ reimpr. São Paulo: Centauro, 2013.

HATOUM, Milton. Dois Irmãos. São Paulo: Companhia das Letras, 2000.

LAGES, Susana Kampff. Walter Benjamin: Tradução e Melancolia. $1^{\text {a }}$ ed. $1^{\mathrm{a}}$ reimpr. São Paulo: Edusp, 2007.

PESAVENTO, Sandra. Cidades imaginárias: literatura história e sensibilidades. Fênix: Revista de História e Estudos Culturais. v. 6, ano VI, n. 1, jan./fev./mar. 2009. Disponível em: <http://www. revistafenix.pro.br/vol18sandra.php>. Acesso em: 24 mar. 2018.

STARONBINSKI, Jean. A melancolia diante do espelho: três leituras de Baudelaire. Tradução de Samuel Titan Jr. 1ª ed. São Paulo: Editora 34, 2014.

VERDE, Cesário. O livro de Cesário Verde. Porto Alegre: L\&PM, 2003. 
